\title{
The Romanian Map of Organic Pollution from Domestic Wastewaters - Seasonal Variations of Anionic Surfactants And Organic Load (COD)
}

\author{
DANIEL MITRU ${ }^{1,2}$, GHEORGHE NECHIFOR ${ }^{1}$, STEFANIA GHEORGHE ${ }^{2}$, \\ IULIANA PAUN ${ }^{2}$, LUCIAN IONESCU ${ }^{2}$, MIHAI NITA-LAZAR ${ }^{2}$, \\ IRINA EUGENIA LUCACIU ${ }^{2 *}$ \\ ${ }^{1}$ Politehnica University of Bucharest, Faculty of Applied Chemistry and Materials Science, Department of Analytical \\ Chemistry and Environmental Engineering, no. 1-7, Polizu Str., 011061, Bucharest, Romania \\ ${ }^{2}$ National Research and Development Institute for Industrial Ecology ECOIND Bucharest, 71-73 Drumul Podul \\ Dambovitei Str., 060652, Bucharest, Romania
}

\begin{abstract}
Surfactants represent the major class of chemicals used in the composition of detergents where the predominant groups are anionic surfactants. Because of the large utilization of detergents in different activities (agricultural, industrial, domestic) an important amount of surfactants can accumulate in the domestic and industrial wastewaters, that are discarded to wastewater-treatment plants (WWTP). Furthermore, surfactants could affect the process of biological wastewater treatment due the inhibition of activated sludge and subsequently the water bodies quality through discharge of WWTPs' effluents. In addition, the soil quality decreased through various modes of sludge applied. The concentrations of organic matters discharged in the wastewater systems from Romania have raised the attention of environmental authorities regarding the toxic impact of their components such as anionic surfactants on the environment. The present paper proposed to highlight the background of organic pollution from Romania through the monitoring of the organics amount in water by Chemical Oxygen Demand (COD) and by the specific indicator - Anionic Surfactants (AS). Temporal (winter, spring and summer, 2019) and spatial (six areas: West, North-West, North-East, East, South and South-West) monitoring of organic matter was performed. It has been found that the spatial and temporal variation of AS concentrations were well correlated with COD load, leading to the conclusion that surfactants represented an important part of the global organic matter.
\end{abstract}

Keywords: anionic surfactants, sewage-treatment plant, COD, dependence

\section{Introduction}

The wastewater discharged in the sewage - treatment plant is often contaminated with different organic and inorganic pollutants. According to the literature the domestic wastewater can be distinguished by emission sources and locations (Figure 1). The yellow and brown water compounds had the provenience from toilets uses, while the greywater includes various emissions: kitchen and laundry activities and personal care products [1]. The source of organic pollutants came from household activities, industrial effluents, and vegetable matter [2].

Chemical Oxygen Demand (COD) is the most common measurement of the organic matter presence in the wastewater sample. Briefly, the amount of oxygen required to oxidize organic matter from the sewage sample is measured by chemical oxidation with a powerful oxidizing agent such as potassium dichromate.

*email:irina.lucaciu@incdecoind.ro 


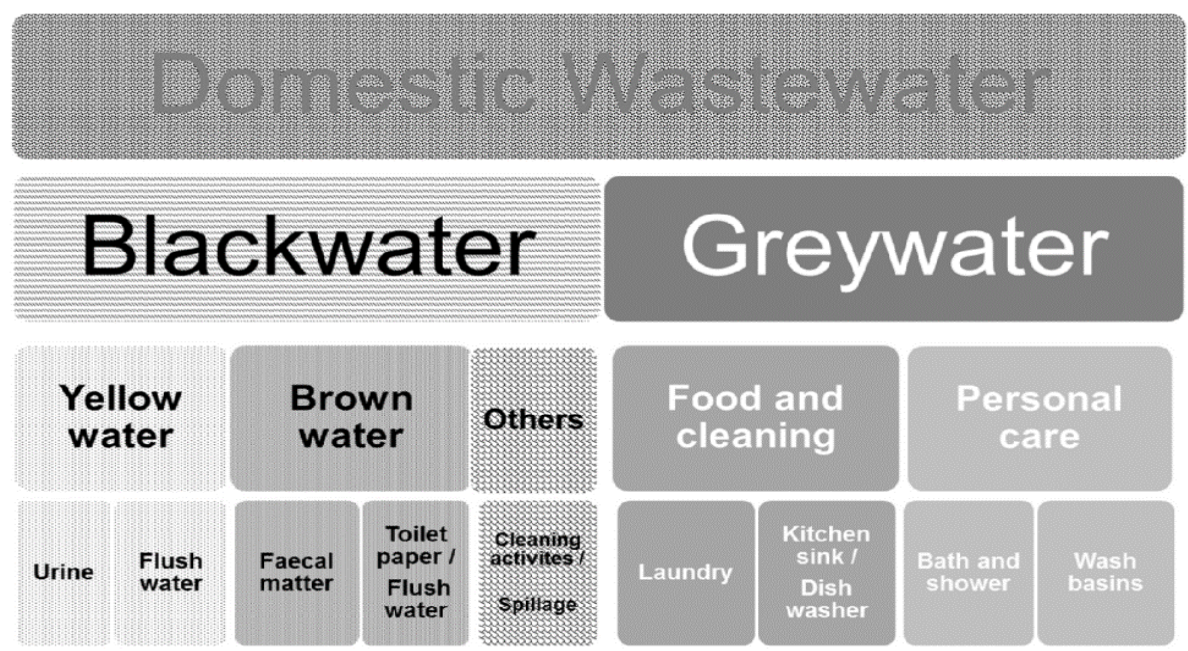

Figure 1. Domestic water classification by source [1]

Four important applications of COD in wastewater treatment are: i) to determine the concentration of oxidized pollutants present in wastewater; ii) to determine overall water quality; iii) to ascertain the effectiveness of wastewater treatment solutions; iv) to determine the effect of wastewater disposal on the receiving environment Surfactants are a diverse group of organic chemicals that are best known for their wide use in detergents and other cleaning products. Because of their wetting, dispersing, solubilizing and foaming properties, surfactants also, enter in the formulation of pharmaceuticals, cosmetics, pesticides, and household products.

The increasing production of surface active products (surfactants) and their widespread use in a lot of activities may be the main source of organic carbon introduced into the aquatic environment [3]. After use, residual surfactants and products of their incomplete biodegradation are continually discharged into sewage systems or directly into surface waters, and most of them end up dispersed in different environmental compartments such as surface water, sediment or soil $[4,5]$. Proper operation process of the Wastewater Treatment Plants (WWTPs), especially the biodegradation step by the activated sludge are negatively affected by the presence of high content of surfactants in the influent that could inhibit the bacterial activity, in spite of their adaptation mechanisms [6-8]. The discharge of wastewater polluted with massive quantities of surfactants could have serious effects on the ecosystem such as: eutrophication of lakes, foam formation in rivers, dispersion and accumulation [9]. The surfactants acumulation at water surface can disturb the life of aquatic organisms because of their toxicity. The interaction between different compounds from the group of surfactants and aquatic species can lead to chronic toxicity or estrogenic responses[9, 10]. The main biological treatment used in WWTP for organic matter biodegradation is with activated sludge flocs [11].

Anionic surfactants (AS) are used as principal constituents of commercial detergents and the predominant chemical groups are linear alkyl benzene sulfonates and linear alkyl sulfates, because of their extensive biodegradation once released into the environment (over 80\%). In spite of the fact that these types of surfactants are reasonably aerobically degradable and not particularly toxic at low concentrations, but at higher concentration (in the range of $15-30 \mathrm{mg} / \mathrm{L}$ ) they could be harmful for the aquatic environment [12-14]. The presence of surfactants in various ecosystems affects the environment by changing his physical and chemical properties [15]. Moreover, in the untreated industrial wastewaters the concentration of AS get up to $1000 \mathrm{mg} / \mathrm{L}$ [16], so they could be harmful for different types of organisms or affect their endocrine balance. Moreover, by interacting with different interfaces (water-air, soil/sediment-water) they can change natural processes in those systems [17].

Linear Alkylbenzene Sulfonates (LAS) are currently the most used anionic surfactants in the formulation of household and laundry detergents, hand dishwashing liquids, shampoos, and other 
personal care products. Commercial LAS are available as a mixture of homologues, with a different length of the alkyl chain (from $\mathrm{C}_{10}$ to $\mathrm{C}_{14}$ ) $[18,19]$.

For all these reasons, it is important to monitor the concentration of surfactants in domestic and industrial wastewaters discharged into WWTPs. The present paper proposed to highlight the background of organic pollution from Romania through the monitoring of the organics amount in water by Chemical Oxygen Demand (COD) and by Anionic Surfactants (AS) from economic units located in different areas of Romania into wastewater collection systems (Figure 2).

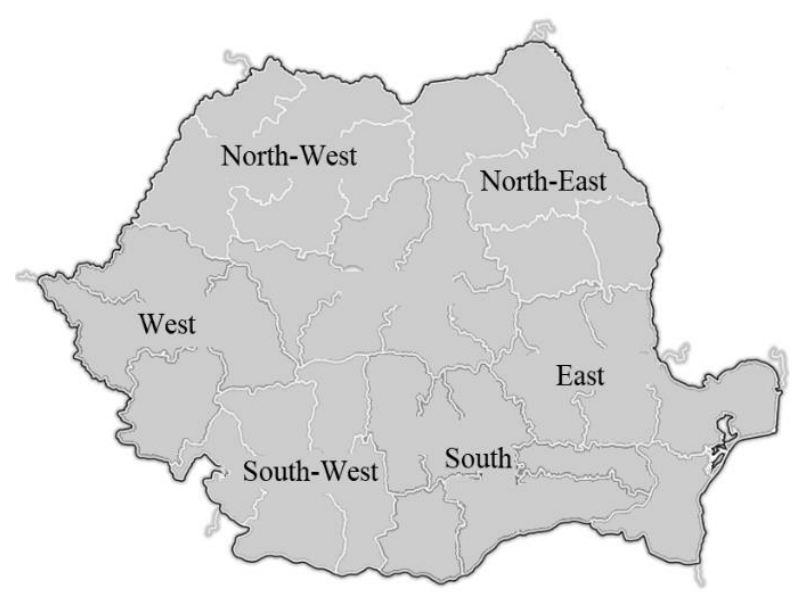

Figure 2. The sampling areas from Romania

The content of anionic surfactants discharged into the sewage system was correlated with the organic loading of wastewaters, expressed as COD, which is very useful indicator for the operation and control of the treatment plants. The influence of these parameters are critically for the quality of wastewaters [20].

\section{Materials and methods}

This monitoring study investigate the COD and the AS concentrations from different domestic wastewaters discharged into wastewater collection systems (city sewerages). Samples were collected during one year with a seasonal frequency (winter, spring and summer, 2019) from various economic units located in Romania. The selected areas for wastewater samples collection were: $i$ ) West represented by Timisoara, Lugoj, Bors and Oradea; ii) North-West represented by Maramures and Satu Mare; iii) North-East represented by Iasi, Vaslui and Galati; iv) East represented by Buzau and Braila; v) South represented by Dambovita, Ilfov-Bucharest and Giurgiu; vi) South-West represented by Teleorman. [21].

The COD analysis were performed according to the Romanian standard method SR ISO 6060:1996

Anionic surfactant concentration was analyzed in accordance with the Methylene Blue Active Substance method (MBAS). The samples are extracted into a $250 \mathrm{~mL}$ separating funnel with chloroform, using doses of 15,10 and $10 \mathrm{~mL}$ and in the presence of neutral methylene blue solution. The extracts were introduced to a volumetric flask $(50 \mathrm{~mL})$ and filled with chloroform to final volume of $50 \mathrm{~mL}$ and adsorption spectra were measured using chloroform as blank at $650 \mathrm{~nm}$, according to the Romanian standard (SR EN 903:2003) [22]. A spectrophotometer Analytic Jena Specord 205 with the ability to acquire spectra in range of 200-1100 nm was used in order to determine the AS concentration (etalon curve with sodium dodecylbenzenesulfonate, CAS 52319-06-9, Merck).

The following important aspects were taken into consideration: the type of wastewater discharged by economic units with similar activity; number of samples correlated with the size of the selected region (for example: from the East and South-West areas were taken 4 grab samples per season, while 
from the Western, North-West and South regions the number of samples was 9 per season). Grab samples of domestic wastewater discharged to the city sewerage from each selected location were taken and stored at $4{ }^{\circ} \mathrm{C}$ until analysis (within $48 \mathrm{~h}$ in all the cases).

The concentrations of COD and AS were monitored seasonally, from January to August 2019. The wastewaters samples were analyzed in two replicate of each sample and the results are presented as a mean value, whereas the standard deviation (SD) was $\leq 2 \%$ in all cases.

\section{Results and discussions}

The seasonal distribution and variability of anionic surfactants in domestic wastewaters has been investigated, considering that AS, even at low concentrations, may strongly affect wastewater treatment efficiency [12].

The AS determination in domestic wastewater was based on the anionic surfactant methyl dodecylbenzensulfonate (Merck, 99\% purity, $\mathrm{M}=340,53 \mathrm{~g} / \mathrm{mol}$ ) calibration curve.

The effects on aquatic environment due the discharged wastewater in sewage systems eould be was evaluated through COD as quality parameter.

The results obtained for the selected global indicator - COD, as well as specific indicator - AS were analyzed considering the admissible concentrations imposed on discharge in natural emissary, in accordance with in the Government Decision no. 352/2005 - norms regarding the conditions of wastewater discharge in the aquatic environment.

The concentration ranges of AS and COD in the wastewater samples were shown in Figure 3 and Figure 4, respectively.
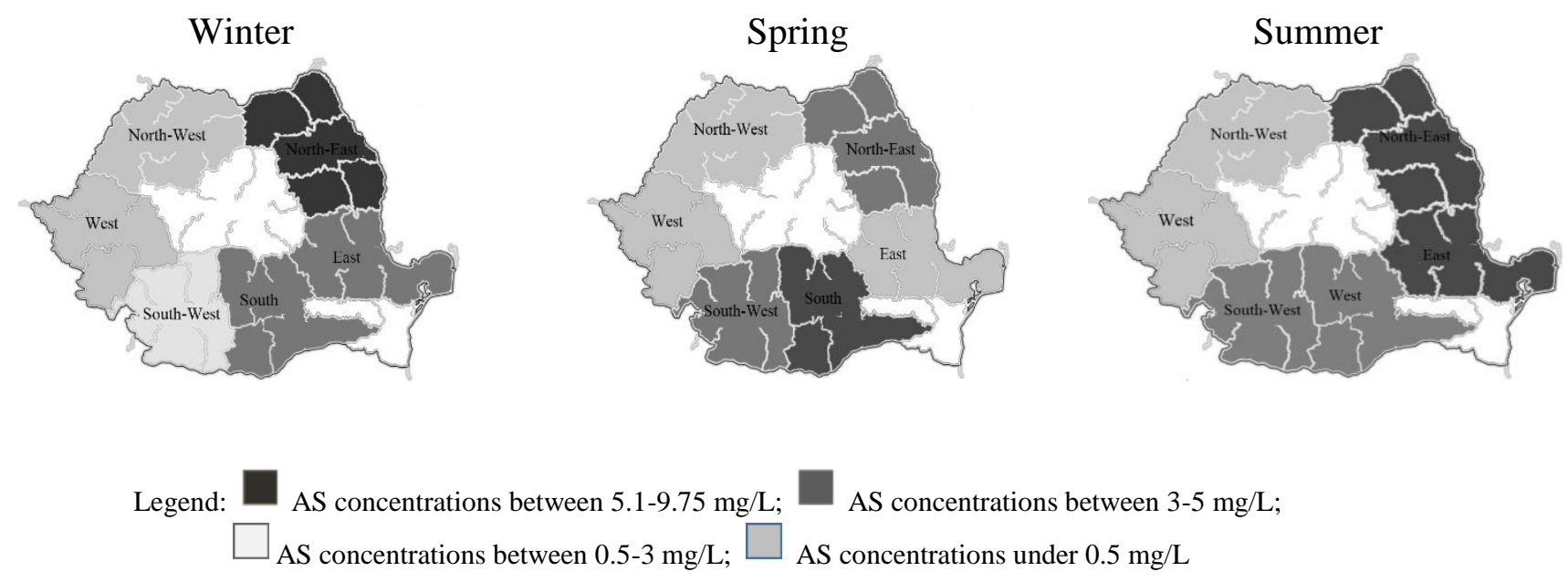

Figure 3. The concentration of AS during 3 seasons
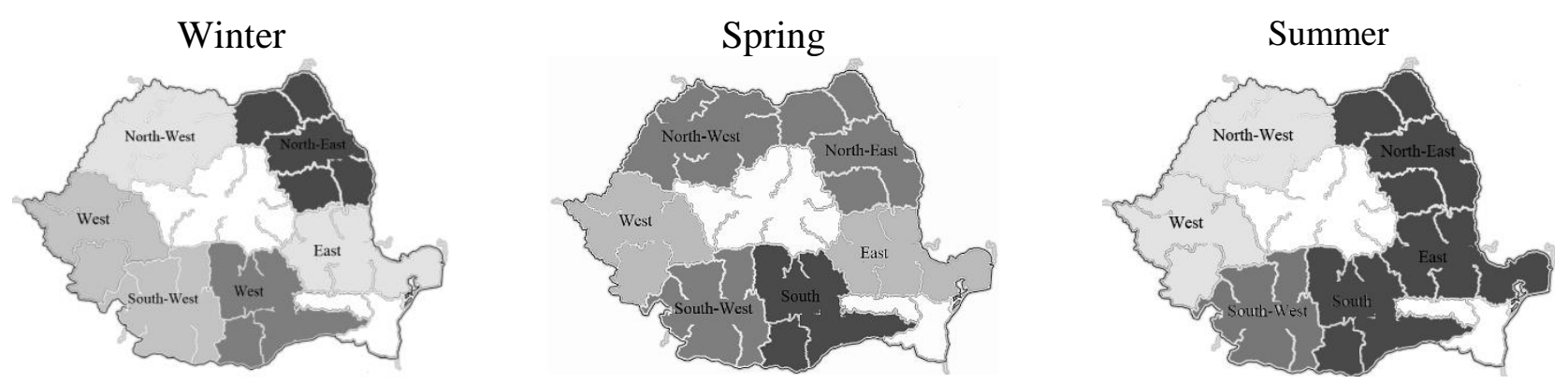

Figure 4. The concentration of COD during 3 seasons 
The concentration of AS ranged from 0.2 to $9.75 \mathrm{mg} / \mathrm{L}$, while the values of organic loading, expressed as COD were in the range $62-900 \mathrm{mg} / \mathrm{L}$. In Figure 5 was graphically highlighted the spatial evolution of the maximum concentrations of AS and COD obtained in the wastewater samples taken with the seasonal frequency, during the January-August 2019 period.

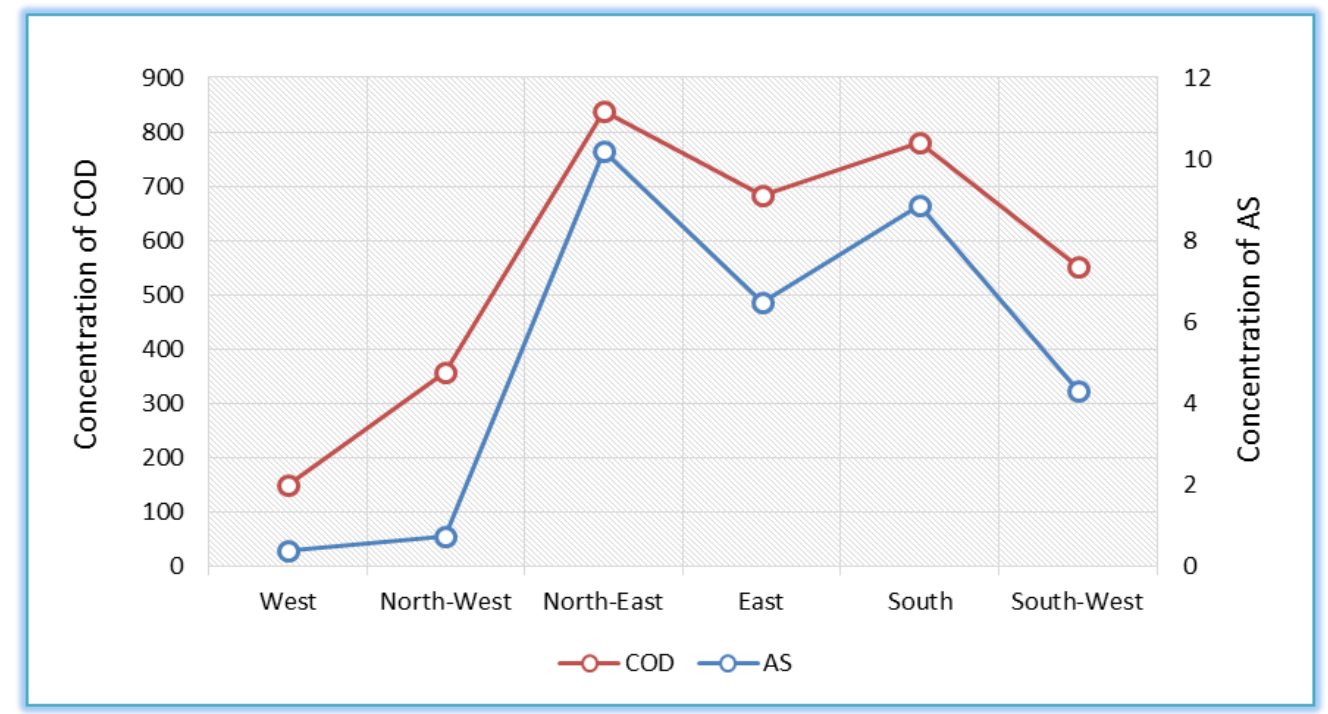

Figure 5. Spatial variation of AS and COD concentrations in domestic wastewater discharged into sewage collection systems from Romania

Spatial evolution of the both monitored parameters has shown that the lowest concentrations of AS and COD were obtained in the regions located in the West and Nord-West part of Romania, while in the Nord-Est and South areas the concentrations are the highest, regardless of the sampling period. AS concentrations, as well as COD values considerably lower for the left side of Romania (including South-West, West and Nord-West) than those obtained in the right side (including North-East, East and South) could be related with the much more developed economic activities in the north-east and south of Romania, compared to the other areas (east, south-west and west).

In the winter season, the wastewaters taken from the North East part of Romania recorded the highest concentration of anionic surfactants (average of $8.5 \mathrm{mg} / \mathrm{L}$ ), followed by South (average of 7 $\mathrm{mg} / \mathrm{L}$ ) and East (average of $6.07 \mathrm{mg} / \mathrm{L}$ ) (fig.3). The lowest concentration was determined in West and North-West $(0.21 \mathrm{mg} / \mathrm{L})$, while in the South-West the concentrations was $1.41 \mathrm{mg} / \mathrm{L}$.

Regarding COD measured in the wastewater samples collected in the same period of time, the results obtained are correlated with the AS concentrations, thus the highest COD concentrations (average of $820 \mathrm{mg} / \mathrm{L}$ ) being in the northeastern part of Romania, while the lowest COD values were in the western part of Romania (average of $62 \mathrm{mg} / \mathrm{L}$ ) (Figure 4).

In the spring of 2019, there was a good correlation between the COD values and the AS concentrations obtained for the wastewater samples taken from the study areas of Romania. Thus, the highest values of the organic loading were obtained in the South (average of $684 \mathrm{mg} / \mathrm{L}$ ), South-West (average of $470 \mathrm{mg} / \mathrm{L}$ ) and North-East (average of $485 \mathrm{mg} / \mathrm{L}$ ) areas, similar to the high content of AS (average of $6.4 \mathrm{mg} / \mathrm{L}-$ South and average of $4 \mathrm{mg} / \mathrm{L}$ - South-West and North-East) existing in the wastewater samples taken from these areas. The lowest concentrations of AS $(<0.5 \mathrm{mg} / \mathrm{L})$ were highlighted in West, Nord-West and East areas. Also, the lowest COD values (average of $64 \mathrm{mg} / \mathrm{L}$ ) were obtained in the West and East locations. The northwestern area was the only one where COD values were in the range $350-500 \mathrm{mg} / \mathrm{L}$, and the content of AS was low $(<0.5 \mathrm{mg} / \mathrm{L})$.

In the summer time, the high level of AS content in all studied areas (average of $9.5 \mathrm{mg} / \mathrm{L}-\mathrm{North}-$ East, $6.2 \mathrm{mg} / \mathrm{L}-$ East and $8.07 \mathrm{mg} / \mathrm{L}-$ South), except West and Nord-West $(<0.5 \mathrm{mg} / \mathrm{L})$ is corroborated with the organic load values obtained in the wastewater samples collected from the same regions 
(COD: average of $805 \mathrm{mg} / \mathrm{L}-$ North-East, $692 \mathrm{mg} / \mathrm{L}-$ East and $748 \mathrm{mg} / \mathrm{L}-$ South; < 125mg/L in West and North-West).

Temporal evolution of AS and COD concentrations measured in domestic wastewater discharged into sewage collection systems showed their highest concentrations in summer sampling period when the domestic economic activities were more intensive than in the winter-spring period.

Because of the huge use of AS, environmental regulatory authorities have fixed limits for anionic surfactants concentration at the entrance to the municipal wastewater treatment plants, as well as at the discharge of effluents into surface water. According to the national legislation (Government decision no. 352/2005), the limit of concentration of surfactants (total of anionic and nonionic surfactants) is 25 $\mathrm{mg} / \mathrm{L}$ at the entrance to the municipal WWTPs and $5 \mathrm{mg} / \mathrm{L}$ into surface water. Also, the content of organic matter expressed as COD is regulated, $500 \mathrm{mg} / \mathrm{L}$ at the entrance to the WWTP and $125 \mathrm{mg} / \mathrm{L}$ for the treated effluents discharged into the surface waters.

The presence of AS in wastewater samples collected from different economic units and discharged into sewage systems are in normal limits according to the Romanian law (highest concentration approximately $10 \mathrm{mg} / \mathrm{L}$, against the limit of $25 \mathrm{mg} / \mathrm{L}$ ).

The content of COD in some investigated areas of Romania (North-Est, Est and South) represents a concern due the high values (above $500 \mathrm{mg} / \mathrm{L}$ - maximum concentration allowed by Romanian law). COD concentrations above the maximum allowed values for wastewater disposal in the sewage system were obtained in same areas, where the highest concentrations of AS were obtained (Figure 5). The lowest concentrations of COD have been recorded in the West area, same location where low AS content was observed.

A considerable number of studies have reported the presence of anionic surfactants in sewage effluents showing concentrations up to $50 \mathrm{mg} / \mathrm{L} \mathrm{[23]} \mathrm{as} \mathrm{well} \mathrm{as} \mathrm{in} \mathrm{surface} \mathrm{waters} \mathrm{[24-25]} \mathrm{at} \mathrm{levels}$ typically ranging from less than $1 \mathrm{ng} / \mathrm{L}$ to several hundreds of $\mu \mathrm{g} / \mathrm{L}$ respectively, depending on the distance from urban wastewater discharge sources and the type of wastewater treatment. Surfactant content in typical municipal sewage usually does not exceed $20 \mathrm{mg} / \mathrm{L}$, but specific wastewater with a high surfactant content (over $50 \mathrm{mg} / \mathrm{L}$ ) can be discharged into sewage and could have a negative influence on the biological process with active sludge usually applied in municipal wastewater treatment plants $[11,26]$. It is very important to check periodically the content of anionic surfactants in domestic sewage due to their possible negative effect on activated sludge. Previous monitoring studies of surfactants content in the different influents to urban / industrial WWTPs from Romania [27], have shown similar results regarding the concentration of anionic surfactants ranged (2.63 to $10.79 \mathrm{mg} / \mathrm{L}$ ), with an average of $6 \mathrm{mg} / \mathrm{L}$.

The present study of the monitoring of AS and organic matter content in domestic wastewaters discharged to the municipal sewerage shown that AS was found in concentrations between 0.2 to 9.75 $\mathrm{mg} / \mathrm{L}$, while the values of organic loading, expressed as COD were in the range: $62-900 \mathrm{mg} / \mathrm{L}$.

\section{Conclusions}

The results revealed that: $i)$ the concentration level of the anionic surfactants in the domestic wastewater collected from different areas of Romania was within the maximum concentration allowed by the national regulations; $i$ ) the organic load expressed as COD determined in the same wastewaters as for AS, exceeded in certain areas of Romania, the maximum value allowed for wastewater discharged into WWTPs; iii) there is a dependence of concentration between AS and COD, the highest concentration of AS $(9.75 \mathrm{mg} / \mathrm{L})$ and COD $(850 \mathrm{mg} / \mathrm{L})$ were obtained in the same area of Romania (North East).

Good correlation of surfactant content from wastewater analyzed with the organic load expressed as COD leading to the conclusion that surfactants represented an important part of the global organic matter.

Further research is in progress to assess effects of anionic and nonionic surfactants on activated sludge oxygen uptake rate and its biological activity. 
Acknowledgement.The authors acknowledge the financial support offered by The National Program Nucleu through Contract no 20N/2019, Project code PN 19040201.

\section{References}

1.BOUTIN, C., EME, C., 13eme congres spécialisé IWA on Small Water and wastewater Systems, Athènes, Greece, 14-16 September 2016.

2.NAYL, A.E.A., ELKHASHAB, Adsorption studies on the removal of COD and BOD from treated sewage using activated carbon prepared from date palm waste, Environ. Sci. Pollut Res., 24, 2017, 22284-22293.

3.KRUSZELNICKA, I., GINTER-KRAMARCZYK, D., WYRWAS, B., JAKUB, I., Evaluation of surfactant removal efficiency in selected domestic wastewater treatment plants in Poland, J. Environ. Health Sci. Eng., 17(2), 2019, 1257-1264.

4.JEFFREY, JS, The evolution of anionic surfactant technology to meet the requirements of the laundry detergent industry, J Surfactants Deterg., 7, 2004, 319-328.

5.STOICA C., VASILE G., BANCIU A., NICULESCU D., LUCACIU I., NITA-LAZAR M., Influence of Anthropogenic Pressures on Groundwater Quality from a Rural Area, Rev. Chim., 68(8), 2017, 1744-1748.

6.NITA-LAZAR, M., GALAON, T., BANCIU, A., PAUN, I., STOICA, C., LUCACIU, I. E., Screening of various harmful compounds in a new bacterial biological model, J. Environ. Prot. Ecol., 17(1), 2016, 237-247.

7.NITA-LAZAR, M., GHEORGHE, S., ANGHELAGHE, A., BANCIU, A., STOICA, C., LUCACIU, I., Modulation of the Bacterial Defense Mechanisms by Various Chemical Structures, Rev. Chim., 67(8), 2016, 1454-1457.

8.WYRWAS, B., KRUSZELNICKA, I., GINTER-KRAMARCZYK D, Effects of selected anionic and nonionic surfactants on the operation of activated sludge., Chemical Industry (Przemysl Chem), 90, 2011, 613-619.

9.MENZIES, J.Z., MCDONOUGH, K., MCAVOY, D., FEDERLE, T.W., Biodegradation of nonionic and anionic surfactants in domestic wastewater under simulated sewer conditions, Biodegradation, 28, 2017, 1-14.

10.DERESZEWSKA, A., CYTAWA, S., TOMACZAK-WANDZEL, R., MEDRZYCKA, K., The Effect of Anionic Surfactant Concentration on Activated Sludge Condition and Phosphate Release in Biological Treatment Plant, Pol. J. Environ. Stud., 24, 2015, 83-91.

11.MANEA, E.L., BUMBAC, C., Performance Evaluation of Continuous Flow Aerobic Granular Sludge Configurations, Rev. Chim, 70 (1), 2019, 283-285.

12.GHEORGHE, S., LUCACIU, I., PASCU, L., Biodegradability assessment of cationic and amphoteric raw materials, J. Environ. Prot. Ecol., 13(1), 2012, 155-163.

13.GHEORGHE, S., LUCACIU, I., GRUMAZ, R., Detergents legislation framework and ecotoxicological testing methodology, J. Environ. Prot. Ecol., 12, 2011, 1525-1532.

14.AGNIHOTRI, S., SUTHAR, S., KHAN, A.A., Performance evaluation of sewage treatment plant based on SBR and MBR technology, IJTIMES, 5, 2019, 98-102.

15.PAUN I., IANCU V.I., CRUCERU L., NICULESCU M., CHIRIAL F.L., Simultaneous Determination of Anionic, Amphoteric and Cationic Surfactants Mixtures in Surface Water, Rev. Chim, 69 (1), 2018, 27-30.

16.ALOUI, F., KCHAOU, S., DAYADI, S., Physicochemical treatments of anionic surfactants wastewater: Effect on aerobic biodegradability, J. Hazard. Mater., 164, 2009, 353-359.

17.CORADA-FERNÁNDEZ, C., LARA-MARTÍN, P.A., CANDELA, L., GONZÁLEZ-MAZO E., Tracking sewage-derived contamination in riverine settings by analysis of synthetic surfactants, $J$. Environ. Monitor., 13, 2011, 2010-2017.

18.GÓMEZ, V., FERRERES, L., POCURULL, E., BORRULL, F. Determination of non-ionic and anionic surfactants in environmental water matrices, Talanta, 84(3), 2011, 859-866. 
19.MONDAL, B., ADAK, A., DATTA, P., Degradation of anionic surfactant in municipal wastewater by $\mathrm{UV}-\mathrm{H}_{2} \mathrm{O}_{2}$ : Process optimization using response surface methodology, J. Photochem. Photobio. A, 375, 2019, 237-243.

20.SR ISO 6060:1996 - Water quality - Determination of chemical oxygen demand.

21.***SR EN ISO 903:2003- Water quality- Determination of anionic surfactants by measuring the methylene blue active substance index (MBAS).

22.OLKOWSKA, E., RUMAN, M., KOWALSKA, A., POLKOWSKA, Ż., Determination of Surfactants in Environmental Samples. Part III. Non-Ionic Compounds, Ecol. Chem. Eng. S, 20(3), 2013, 449-461.

23.SARKKA, H., VEPSALAINEN, M., SILLANPAA, M., Natural organic matter (NOM) removal by electrochemical methods - A review, J. Electroanal. Chem., 755, 2015, 100-108.

24.CHEN, G., Electrochemical technologies in wastewater treatment, Sep. Purif. Technol., 38, 2004, 11-41.

25.SULEJ, A., POLKOWSKA, Z., NAMIESNIK J., Contaminants in Airport Runoff Water in the Vicinities of Two International Airports in Poland, Pol. J. Environ. Stud., 21(3), 2012, 725-739.

26.MITRU D., LUCACIU I. E., GHEORGHE S., STOICA C., BANCIU A.R., IONESCU L., IONICA D.L., NECHIFOR G., Book of abstracts, $22^{\text {nd }}$ International Symposium "The Environment and the Industry”, Bucharest, 26-27 September 2019, 73-75.

Manuscript received: 18.12 .2019 